\title{
Health Assessment of Urban Land Ecosystem: A Case Study in Chengdu $*$ YIN Qi ${ }^{1, a^{*}}$, CHEN Wenkuan ${ }^{1, b}$, ZENG Wenjia ${ }^{1, c}$ ZHOU Ting ${ }^{1, d}$ \\ 1 College of Management, Sichuan Agricultural University, Chengdu, China, 611130

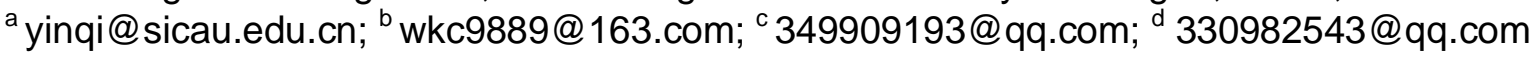

\section{Keywords: Urban land ecosystem; Health; Assessment; Chengdu}

Abstract: This study was conducted to discuss the index and method of urban land ecosystem health assessment; and to evaluate the condition of land ecosystem health in Chengdu. The assessment index system of 'vitality-organizational structure- resilience-ecosystem service functionlife style' was established; comprehensive evaluation method and clustering analysis method were used to calculate the health score and to class the health condition in research area. The result is that among the years from 2001 to 2009 which were studied, it was healthy in 2005, 2006 and 2008; unhealthy in 2001 and 2002, and sub-healthy in the rest years. And the conclusion is the index system of 'vitality-organizational structure- resilience-ecosystem service function-life style' as well as comprehensive evaluation method and clustering analysis method is able to evaluate the health condition of urban land ecosystem well. For Chengdu, it is suggested that the government should make decisions which help the system to release the vitality, strengthen the resilience and service function; and the public should establish the awareness to protect the land ecosystem health.

\section{Introduction}

The concept of "Land Health" appeared in the 1940s ${ }^{[1]}$. But until 1980s, the program "Land Health" was just first launched by Canada, whose essence is to investigate and study national soil quality. ${ }^{[2]}$ In recent decades, some scholars in China and abroad have studied land health. But their results still remained in concepts and the progress in other fields was still slow. For example, Chen Meiqiu thought that land health was the land maintains its normal metabolism. Its resilience can mitigate the adverse impact on land ecosystem from outside, which is to maintain the development of symbiosis, mutualism and regeneration between land and human, different organisms, organism and inorganic environment. ${ }^{[3]}$ Cai Weimin pointed that healthy land use system is based on the sustainable development of society, to promote the harmony and unity among economy, society and ecology, composed by the structure, function and benefit of land use system, when he talked about the health of land use system. ${ }^{[4]}$

Now the study fields about the health of ecosystem involve grassland ecosystem ${ }^{[5]}$, ecosystem of lakes valley ${ }^{[6]}$, wetlands ecosystem ${ }^{[7]}$, etc. But the study of urban land ecosystem is still nearly vacant. Relevant theoretical basis need to be traced to its principal branches of "global ecosystemterrestrial ecosystem - urban ecosystem - urban land ecosystem". With the study results related to the health of ecosystem in academia, for the economy attributes and social effects of urban land, this paper holds that healthy urban land ecosystem has following features:(1) supplying people with high benefit materials and energy for their diverse demands;(2)owning the authority of reasonable allocation of urban land resources and sustainable resource utilization and life styles;(3) it shows certain resilience to mitigate impact from outside and has enough resilience to maintain system structure and organization's stability when it fights against natural disasters or human's excessive activities $^{[8]}$. From the viewpoint of benefits, its service value does not decrease as time goes by ${ }^{[9]}$. From the viewpoint of getting external force, the more natural it absorbs the energy and the less external force it gets, the healthier the land system is. 


\section{Health Assessment of Urban Land Ecosystem}

Urban land ecosystem is a typical artificial ecosystem. It is composed of people's specific demands and the realization of urban functions. Its stability is based on all human economic and social activities. It is not the "urban land ecosystem" without human factor. As for Chengdu, its main terrain is almost plains and hills. The urban land ecosystem here is probably replaced by desert ecosystem or forest ecosystem without human activities.

\section{Construction of Evaluation Model}

The construction of evaluation model is the key point of health assessment of land ecosystem. But so far, there has no unified evaluation method and criteria because of the complexity of evaluation subject, variability of influencing factors, difficulty of indicator quantification, etc. ${ }^{\text {[10] }}$ Now the "indicator species" and "structure and function index" is often used for evaluating natural land ecosystem. And the system "pressure-state-response (PSR)" is widely used in human land ecosystem ${ }^{[11]}$. It is a conceptual framework of land quality index. It aims to measure the pressure to land resource from human activity with ecological land quality index, study the effects on land quality state for the pressure, see human's response to these changes, and involve land quality index with relevant policies and administrative decisions.

As relevant study goes on, some scholars, based on PRS, according to the structure and function process of ecosystem ${ }^{[12]}$, or with the evaluation category of the health of ecosystem- three features: vitality, organizational structure and resilience, build index system: Li Weihai regarded "vitality-organization-function-resilience" as the indicator of S(state) in PSR and analyzed the health of ecological environment in Guiyang ${ }^{[13]}$; Guo Xiurui, etc. also had innovation in the study of the health assessment of urban ecosystem and build the system "vitality-organizational structureresilience-sustainability of ecosystem function-health condition of people". ${ }^{[14]} \mathrm{Ni}$ Zhen studied the assessment system of the health of real estate ecosystem in Chongqing with the system "vitalitylife-resilience-indicator of self-sustaining-ecological service-innovation" ${ }^{[15]}$. According to the land ecosystem's features, such as service value and social economy attributes, etc. in Chengdu, in the light of obtained achievements, with the system "vitality-organizational structure-resilienceecosystem service function-lifestyle", adhere to the principles of data availability, regionalism, scientificity, representativeness, objectivity, warning ${ }^{[16]}$, etc, this paper is to assess the health of urban land ecosystem of study area by selecting proper indicators.

\section{Screening of Evaluation Indexes}

Economy growth is the fundamental driving power of promoting the city's development. GDP growth rate in selected region reflects regional macro economy development; CPI shows purchasing power and overall living standard of city people. Besides, housing, as a hot livelihoods topic, is closely related to real estate. And real estate is the key factor in land market activation. Its shares in marketing economy must be taken seriously. Therefore, the residential investment in the selection of total real estate investment reflects the "vitality" level of land ecosystem in Chengdu.

The proportion and structure of resource allocation of urban land ecosystem have an important effect on city efficiency. And the continuous increasing urban population is a direct factor for causing city disease; the expenditure on scientific education in local finance guarantee the top power for training human resource and urban innovation; the change of urban development land's proportion in urban area shows the urban development's demands tendency towards non-agriculture land and indirectly reflects the transformation of economic structure. Therefore, three indicators are selected to reflect "organizational structure" of the system: population density, expenditure on scientific education in local finance and urban development land's proportion in urban area.

The sustainable stability of urban land ecosystem also depends on system's resilience. The direct reason for imbalance of land ecosystem is the land disuse and abandonment. And cultivated land is an important factor to ensure food security and maintain social stability. Therefore, cultivated land area increased by land consolidation is selected to show the system's elementary resilience. The disposal of waste water, exhaust gas and solid wastes, except that of land resource, is also an important indicator to show system resilience. Therefore, two indicators are selected to 
reflect the "resilience" of system: land consolidation of increasing cultivated land and the product value of multipurpose use of three wastes.

Maintaining healthy urban land ecosystem is to serve human survival and development. Medical resources greatly decide people's physical health; Transportation reflects city's capacity which is the bottleneck of urban development; besides, people's values and social fortunes are embodied and produced in their jobs through working. Whether the system can continuously offer city people with job opportunities of proper types and numbers is also important indicator to show its resilience. Therefore, the number of doctors, average personal urban road space and year-end registered number of unemployment are selected to reflect "ecosystem service function" of the system.

Lifestyle directly reflects urban population quality. Advocating low carbon life is helpful for strengthening people's awareness of protecting ecosystem and plays an active role in promoting sustainable utilization of resources. Therefore, two indicators are selected to reflect "lifestyle" of urban residents: necessary power consumption and water consumption in town daily life.

\section{Determination of indexes, weights, and values}

As indicators' contribution to the system is different, every indicator needs to be weighted. In order to be more scientific, objective weighing method-entropy method will be firstly used. Then subjective weighing method-analytic hierarchy process will be used to revise the weights, according to the facts, and indicators' final weights will appear.

Table 1 The indexes, weights and the values of urban land ecosystem health evaluation system in Chengdu, China

\begin{tabular}{|c|c|c|c|c|c|c|c|c|c|c|c|}
\hline aluation index & $\begin{array}{l}\text { Evaluation } \\
\text { factor }\end{array}$ & $\begin{array}{l}\text { weight } \\
\text { W }\end{array}$ & $\begin{array}{l}2009 \\
\text { year }\end{array}$ & $\begin{array}{l}2008 \\
\text { year }\end{array}$ & $\begin{array}{l}2007 \\
\text { year }\end{array}$ & $\begin{array}{l}2006 \\
\text { year }\end{array}$ & $\begin{array}{l}2005 \\
\text { year }\end{array}$ & $\begin{array}{l}2004 \\
\text { year }\end{array}$ & $\begin{array}{l}2003 \\
\text { year }\end{array}$ & $\begin{array}{l}2002 \\
\text { year }\end{array}$ & $\begin{array}{l}2001 \\
\text { year }\end{array}$ \\
\hline \multirow{3}{*}{ Vitality } & $\mathrm{X} 1$ & 0.0423 & 61.905 & 0.000 & 100.000 & 40.476 & 33.333 & 35.714 & 21.429 & 23.810 & 35.714 \\
\hline & $\mathrm{X} 2$ & 0.0709 & 100.000 & 16.110 & 68.122 & 6.044 & 78.306 & 0.000 & 61.485 & 43.451 & 4.578 \\
\hline & $\mathrm{X} 3$ & 0.0907 & 100.000 & 93.272 & 92.609 & 49.463 & 22.849 & 6.540 & 7.268 & 3.199 & 0.000 \\
\hline \multirow{2}{*}{$\begin{array}{l}\text { rganizational } \\
\text { structure }\end{array}$} & $\mathrm{X} 4$ & 0.0732 & 4.414 & 0.000 & 12.053 & 20.480 & 21.598 & 43.220 & 58.098 & 91.761 & 100.000 \\
\hline & $\mathrm{X} 5$ & 0.0967 & 100.000 & 85.988 & 23.517 & 27.059 & 6.728 & 16.971 & 14.688 & 3.275 & 0.000 \\
\hline \multirow{2}{*}{ Resilience } & $\mathrm{X} 7$ & 0.1103 & 78.338 & 94.113 & 100.000 & 50.638 & 11.836 & 0.000 & 4.711 & 2.800 & 0.323 \\
\hline & $\mathrm{X} 8$ & 0.1396 & 100.000 & 40.757 & 16.500 & 14.937 & 6.322 & 10.346 & 0.992 & 0.140 & 0.000 \\
\hline \multirow{3}{*}{$\begin{array}{l}\text { system service } \\
\text { function }\end{array}$} & X9 & 0.0693 & 100.000 & 73.055 & 49.262 & 25.818 & 16.470 & 13.546 & 0.000 & 14.016 & 15.518 \\
\hline & X10 & 0.0419 & 100.000 & 72.482 & 58.813 & 55.576 & 81.475 & 62.770 & 65.827 & 3.237 & 0.000 \\
\hline & $\mathrm{X} 11$ & 0.0600 & 13.192 & 0.000 & 38.973 & 11.965 & 69.740 & 75.138 & 22.516 & 27.612 & 100.000 \\
\hline
\end{tabular}

Data sources: "urban statistical yearbook of China", "China's land resources Yearbook",

"statistical yearbook of Sichuan".

X1: Region GDP growth rate (\%)

$\mathrm{X} 2$ : The level of consumption index

$\mathrm{X} 3$ : Residential real estate investment in total investment (million)

$\mathrm{X} 4$ : The population density (persons / sq km)

X5: Science Education in local fiscal expenditure (yuan)

X6: Urban construction land for the urban area proportion (\%)

X7: Cultivated land area increased by land consolidation (hectare)

$\mathrm{X} 8$ : The comprehensive output of waste product utilization (million)

$\mathrm{X} 9$ : The number of doctors (person)

$\mathrm{X} 10$ : Per capita urban road area $\left(\mathrm{M}^{2}\right)$

$\mathrm{X} 11$ : The year-end urban registered unemployment (person) 
X12: Electricity consumption for residents (10000 KWH)

$\mathrm{X} 13$ : Water consumption for residents (tons)

0 represents minimum and 100 represents maximum, each value is between 0 and 100 after standardization.

\section{Health Assessment of Urban Land Ecosystem of Chengdu}

\section{General Situation of Chengdu}

Chengdu is located in the interior of Sichuan province, China. It covers $12,390 \mathrm{~km}^{2}$ with fertile soil. Its population is about 14,050,000. Subtropical monsoon climate whose annual average temperature is $16^{\circ} \mathrm{C}$ and annual rainfall is about $1,000 \mathrm{~mm}$. It is usually cloudy and foggy. The sunlight time is short and the air is humid. It is the political, economic, cultural center of Sichuan province. Chengdu is selected as the best tourist city due to its rich and unique natural landscape and biological resources. It also has the best international image. It is a gourmet capital in the world. And it is selected as one of the cities whose economy grows the fastest in the world. As prosperity strategies, like "transportation first", "industry double-increase", "three circles system", etc. deployed, there is an increasing demand for urban resources for human survival and development. Regional land using patterns and spatial patterns are continuously changing dramatically, which greatly decides the structure of regional urban land ecosystem. All these influence the health and stability of urban land ecosystem in Chengdu.

\section{Health Score Calculation and Health Grading}

Figures after applying dimensionless method above will be the parameters for all evaluation indicators. Multiply each indicator's weight by its parameter is the comprehensive score of the year. Then divide yearly average score by the sum of minimum and maximum. Calculating with the following formula (formula 1), and the result of health assessment will appear ${ }^{[6]}$. (See table 2)

$$
G=\frac{X_{\mathrm{i}} \times W_{\mathrm{i}}}{\left[\max \left(\mathrm{X}_{\mathrm{i}} \times \mathrm{W}_{\mathrm{i}}\right)+\min \left(\mathrm{X}_{\mathrm{i}} \times \mathrm{W}_{\mathrm{i}}\right)\right]} \quad(\mathrm{i}=1,2, \ldots, \mathrm{n})
$$

In Formula $1, \mathrm{X}_{\mathrm{i}}$ is the parameter for all indicators. $\mathrm{W}_{\mathrm{i}}$ is the weight for all indicators. $\mathrm{G}$ is the score of health assessment of urban land ecosystem. Basing on the grading method that grading by the comprehensive score of assessment of land intensive use, combining the philosophy of clustering, according to the similarities or differences of the data, the yearly health conditions for the study region are divided into three grades with Euclidean distance method: Healthy, Subhealthy and Unhealthy ${ }^{[6]}$. The score and health features of each grade are shown in table 2. 
Table 2 The results of urban land ecosystem health assessment and the main health characteristics in Chengdu

\begin{tabular}{|c|c|c|c|}
\hline Health level & year & $\begin{array}{l}\text { health } \\
\text { Assessment } \\
\text { values }\end{array}$ & Main land ecological health representations in Chengdu \\
\hline \multirow{3}{*}{ Healthy } & 2006 & 0.6953 & $\begin{array}{l}\text { Residential investment in the total real estate investment and the area of cultivated } \\
\text { land increase fast, and land consolidation increases, and the living water } \\
\text { consumption of residents is the least; The numbers of doctors and year-end } \\
\text { registered urban unemployed personnel are in stability, and urban consumer price } \\
\text { index is low. }\end{array}$ \\
\hline & 2008 & 0.6414 & $\begin{array}{l}\text { In the Living consumption of cities and towns, the electric consumption is the } \\
\text { least, and urban construction land accounts for the highest proportion of the city; } \\
\text { Regional GDP growth is slowing down, and the population density has reached a } \\
\text { peak, and the year-end registered urban unemployed personnel are at a great } \\
\text { number }\end{array}$ \\
\hline & 2005 & 0.6160 & $\begin{array}{l}\text { Consumer Price Index is higher; land consolidation increases and the area of } \\
\text { cultivated land increases fast; Per capita area of urban road is large, and } \\
\text { comprehensive utilization of "three wastes" product output and the number of } \\
\text { doctors are stable; The proportion of the urban construction land in city } \\
\text { downtown areas is lower. }\end{array}$ \\
\hline \multirow{4}{*}{ Sub healthy } & 2009 & 0.6061 & $\begin{array}{l}\text { Residents Consumer Price Index is the highest, and residential investment in the } \\
\text { total real estate investment is large, and local fiscal spending on science and } \\
\text { education accounts for a lot, and comprehensive utilization of "three wastes" } \\
\text { product output is high; Regional GDP growth is slowing down; the population } \\
\text { density is relatively large, and the living water consumption of residents is the } \\
\text { most; }\end{array}$ \\
\hline & 2004 & 0.5965 & $\begin{array}{l}\text { Regional GDP is growing rapidly, land consolidation increases and the area of } \\
\text { cultivated land increases fast, and the living water consumption of residents is } \\
\text { small; Consumer Price Index of residents is low, The proportion of urban } \\
\text { construction land in city downtown areas is smaller, and land consolidation } \\
\text { increases and the area of cultivated land is the least; }\end{array}$ \\
\hline & 2007 & 0.5392 & $\begin{array}{l}\text { Regional GDP is growing rapidly, land consolidation increases and the area of } \\
\text { cultivated land is the biggest, and consumer Price Index of residents is higher, the } \\
\text { population density is relatively large, and year-end registered urban unemployed } \\
\text { personnel are more, and the living water consumption of residents is larger; }\end{array}$ \\
\hline & 2003 & 0.4663 & $\begin{array}{l}\text { The index of residents' consumption level is higher; and the population density is } \\
\text { relatively small; Regional GDP growth rate is low, and comprehensive utilization } \\
\text { of "three wastes" product output is low, and the number of doctors is the least, and } \\
\text { the proportion of urban construction land of city downtown areas is the largest. }\end{array}$ \\
\hline \multirow[t]{2}{*}{ Unhealthy } & 2001 & 0.3100 & $\begin{array}{l}\text { Consumer Price Index of residents is the lowest, and local fiscal spending on } \\
\text { science and education accounts for a little, and the proportion of urban } \\
\text { construction land in city downtown areas is smaller, and per capita area of urban } \\
\text { road is small, and the population density is relatively small; Year-end registered } \\
\text { urban unemployed personnel are the least; the population density is relatively } \\
\text { small, and year-end registered urban unemployed personnel are the least; }\end{array}$ \\
\hline & 2002 & 0.3047 & $\begin{array}{l}\text { the population density is relatively small, and the living water consumption of } \\
\text { residents and living electric consumption is small ; The index of residents' } \\
\text { consumption level is low, and the number of doctors is small, and "three wastes" } \\
\text { product output is low, and the number of doctors is the least; Land consolidation } \\
\text { increases and the area of cultivated land is small. }\end{array}$ \\
\hline
\end{tabular}

\section{Results and Analysis}

From table 2, we can see that the average health score of urban land ecosystem of Chengdu is 0.5306. Three years' scores are below average: year 2001, 2002 and 2003. The system health conditions of most years are healthy and sub-healthy, except the year 2001 and 2002. In the 9 years that are studied, the health score of the system has increasingly accelerated since 2002. From 2004 to 2009 , the health condition is generally going up steadily and slightly. After reaching its peak in 2006, it just goes down in 2007. The score boundary between healthy and sub-healthy is not obvious, which means the developing tendency is relatively steady. Besides, some big or maximum value of negative indicator appear in healthy year, e.g. the maximum of yearly-end registered town 
unemployment appears in healthy year 2008, however, its numerical value is reasonably balanced compared with its near years'. So the negative impact on the health score of the year is not very obvious.

In studying years, Chengdu is influenced by " 5.12 Wenchuan earthquake" of 2008 . Indicators related to economical activity are influenced obviously. The GDP growth proportion and CPI of the year are lower than those of last year; But after the disaster, Chengdu people's consumption ideas changes from overall frugal consumption to moderate consumption, which greatly provokes economy development. Till year 2009, the two indicators above recover a lot. Meanwhile, the government strengthens its regulation to maintain the stability of system organizational structure and ecosystem's service function. So the indicators of medical treatment, science and education, proposal of three wastes, personal average urban road space, etc in the year are relatively stable.

The policies which were carried out by Chengdu city government played a positive role in the development of health system, also reflecting on the resilience and lifestyle index, such as the issue of energy-saving and emissions reduction environmental protection laws and regulations. After carrying out these laws and regulations, the residents, to some extent, turn to low-carbon life style such as water-saving and power-saving. Especially since the implement of "law of the People's Republic of China on the prevention and control of environmental pollution" in 2005, the value of comprehensive utilization products of "three wastes" sharply raised at the end of the year, achieving a remarkable result. Another example is that the policy trend of city, energy, circular economy and industrial development is the wind indicator of development of related industries, and the ups and downs of index have become a barometer of reflecting the policy effectiveness.

\section{Conclusions and Suggestions}

The theory study about the health of ecosystem is still in debate, among which, study on ecosystem health of urban land, as a research branch, belongs to a comparatively advanced research field. Through the research of this paper, it shows that the assessment index system "vitalityorganizational structure- resilience-ecosystem service function-life style" as well as comprehensive evaluation method and clustering analysis method are able to evaluate the health condition of urban land ecosystem well. Meanwhile, more studies regarding urban land's ecosystem health should be done by complying with the research framework of ecosystem health, considering urban land it self's characteristics as well as relevant subject content such as land economy, ecology health and so on, and taking full advantage of modern means like 3S technology ( GIS, RS and GPS). It is duty-bound for researchers to have a clearer understanding towards establishment of urban land's ecosystem, master its operating mechanism, conform to rules, control and avoid human beings' excessive interferences and constantly improve its health condition in order to keep a stable and sustainable urban land ecosystem.

Human can do nothing when facing nature law. The more we can do is to obey it and make good use of it, which is the first rule for carrying out human activities. Besides, as urban land ecosystem is a human social system, the health development of the system depends on human subjective initiative. From the empirical analysis of Chengdu, we can see that the health indicators of urban land ecosystem of Chengdu are greatly influenced by government's actions and decisions. Therefore, to improve the health condition of urban land ecosystem of Chengdu better, it is necessary to emphasize technical innovation and reasonable planning, to maintain the system's vitality and to optimize the system's organizational structure, on the basis of ensuring economic growth. And proper ecological restoration is needed to strengthen the system's resilience, if necessary. Besides, more continuous protection of nature landscape and resources of ecosystem, rational and appropriate use of system resource and the promotion of low-carbon lifestyle are also effective ways to build a more harmonious environment for the health of urban land ecosystem.

\section{References}

[1] Leopold A. Wilderness as a land laboratory [J].Living Wilderness, 1941(July):3. 
[2] Leng Shuying Li Xiubin New Progresses of International Study on Land Quality Indicators (LQIs) [J]. Acta Geographica Sinica, 1999,54(1):177 185. (in Chinese)

[3]Chen M Q, Wu C F. Research Review on Land Health [J]. Acta Agriculturae Universitis Jiangxiensis, 2002 (6) : 324 329. (in Chinese)

[4]Cai W M, Tang H J, Chen Y Q,et al. Framework of conception and Option of Health Assessment Index in Land Use System [J]. China Population, Resources and Environment,2004 (14) : $31 \sim 35$.

[5]He G L. Inner Mongolia Typical Steppe Ecosystem Service Function and Health Assessment [D]. Inner Mongolia: Inner Mongolia University Dissertation for Master Degree,2009.

[6]Chen M Q, Huang L,Cai H S et al. Evaluation of land health in Poyang lake area [J]. Journal of Natural Resources,2004,3 (2):170 175.

[7]Cui B S, Yang Z F. Research Review on Wetland Ecosystem Health [J]. Chinese Journal of Ecology, 2001,20(3):31 36.

[8]Keynote Address. The Health of the World Lands: A Perspective [M].7th International Soil Conservation Organization Conference, Sydney, 1992.

[9]Chen M Q, Liu T J, Huang L. On major contents and problems of land ecosystem health research [J]. Ecology and Environment, 2004,13 (4) 698 701.

[10]Li J T, Tan S K. Empirical Study of Spatial-temporal Differences of Urban Land Use Intensity Based on DPSIR Model: A Case of Hubei Province [J]. China Land Science, 2009,3 (3) :49 65.

[11]Zhang F R. Theory and Practice of Sustainable Land Administration [M].Beijing: Peking University Press, 1996.

[12]Kong H M, Zhao J Z, Ji L Z et al. Assessment method of ecosystem health [J]. Chinese Journal of Applied Ecology,2002,13(4):486 490.

[13]Li W H. expansion of Urban space in Guiyang and analysis of Eco-Environment Health [D].Guiyang, Master Dissertation of Guiyang Normal University,2009.

[14]Guo X R, Yang J R, Mao X Q. Primary studies on urban ecosystem health assessment [J]. China Environmental Science, 2002,22(6):525-529.

[15]Ni Zhen. The Study of Real estate ecosystem and its health Evaluation index system-Take Chongqing as the example [D].Chongqing: Master Dissertation of Southwest University,2010.

[16]Xiao F J, OuYang H. Ecosystem health and its evolution indicator and method [J]. Journal of Natural Resources, , 2002, 17(2):203 209. 